\title{
IMPROVED METHOD FOR DETERMINATION OF ANIONS PRESENT IN AQUEOUS SAMPLES BY ION-CHROMATOGRAPHY
}

\author{
Florentina Laura Chiriac $^{1,2}{ }^{\text {, Toma Galaon }}{ }^{1}$, Liliana Cruceru ${ }^{1}$
}

${ }^{1}$ INCD-ECOIND Bucharest Drumul Podu Dambovitei 71-73, Sect. 6, 060652 , Bucharest, Romania, email:Iaura.badea88@yahoo.com

2Universitatea din Bucuresti,Bdul Regina ElisabetaNr. 4-12, Sector 3, Bucuresti 030018 Romania

\begin{abstract}
In order to protect the environment there have been developed various methods allowing determination of different pollutants in several environmental matrices (wastewater, surface water, drinking water). Many of the methods used so far have proved to be insufficiently sensitive, selective and accurate or time consuming. Recently much attention has been paid to ion chromatography, which seems to be one of the most promising method. A direct ion chromatographic method of measuring common inorganic anions, such as fluoride, chloride, nitrite, bromide, nitrate, phosphate and sulphate was modified and expanded to include measurement of three new components, listed by eluting order: acetate, formate and chromate. In this method, samples were injected using a large-volume direct injection technique, the analyte anions were separated on a carbonate based anion-exchange column using isocratic carbonate/bicarbonate eluents and suppressed conductivity detection method.
\end{abstract}

Keywords: acetate, formate, chromate, inorganic anions, ion chromatography

\section{Introduction}

Over the past few years, ion chromatography (IC) has developed into a significant chromatographic technique for ion analysis within the field of separation science.

The technique is applicable to the determination of a wide range of solutes: inorganic anions, inorganic cations including alkali metal, alkaline earth, transition metal and rare earth ions; low-molecular weight (water soluble) carboxylic acids, such as acetic and formic acid, plus organic phosphonic and sulfonic acids, including detergents, carbohydrates, low-molecular-weight organic bases, and ionic metal complexes[1-3]. Despite the diverse range of solutes and sample types currently analyzed by IC, environmental analysis continues to be the largest application area in terms of new instrument sales and the total number of samples analyzed. In terms of the solutes analyzed in environmental applications of IC, inorganic anions are by far the most important. The primary reason for this is the lack of alternative methods for anion analysis, which is not the case for cations, where many other instrumental techniques are available. Consequently, the simultaneous analysis of the common inorganic anions in drinking water and wastewater remains the most important routine application of IC.[4] Ion chromatography can now be considered a well established, mature technique for the analysis of ionic species and many standard organizations, such as ASTM, ISO, EPA, AWWA, etc., have standardizated methods of analysis based upon IC.[5-8]

The majority of the approved methods are for the analysis of anionic solutes, rather than for cations. IC is a well established technique for the analysis of inorganic anions and its initial acceptance was very rapid, primarily due to the lack of alternative methods which could determine multiple anions in a single analysis. However, the 
situation regarding the analysis of cations in drinking water is quite different. Many rapid and sensitive methods, such as AAS, ICP-AES, and ICP-MS, are available for cation analysis. Many of these are multi-element techniques, hence duplicate one of the major attractions of chromatographic methods.[9]

Recent developments in the field of IC, such as the use of higher capacity columns, larger loop injections, more complex sample preparation and detection schemes, have been incorporated into new approved methods to allow the determination of common inorganic contaminants with other inorganic pollutants such us chromate or organic acids (acetic and formic acid).

\section{a. Common inorganic anions}

Due to their toxicity, the concentrations of inorganic anions in drinking water are regulated. For example: high levels of fluoride can cause skeletal and dental fluorosis; nitrite/nitrate can cause methemoglobinemia, a condition which can be fatal to infants, ozonation of drinking water containing bromide can result in the formation of bromate, a potential carcinogen, even at low $\mu \mathrm{g} / \mathrm{L}$ concentrations. Even secondary contaminants, such as chloride and sulphate, can affect odour, colour and other aesthetic characteristics of drinking water.

b. Organic acids

Ozone is frequently applied during drinking-water treatment, mainly for disinfection purposes but also to break down taste and odor compounds. Other reasons for its utilization include color removal and pretreatment. Organic compounds which are present naturally, especially in surface water, are oxidized during ozonation, and organic acids and aldehydes are formed as well as a range of other products. [10] Various short-chain aliphatic organic acids (for example formate, acetate and oxalate) have been identified and quantified in partially treated water as a result of the utilization of ozone during drinking-water treatment. Since these compounds are suspected to contribute to bacterial regrowth in drinkind water distribution systems, there is considerable interest in being able to quantify these organic acids. Currently, there are several different methods available for the quantification of organic acids. They include gas chromatography (GC)[11], high performance liquid chromatography (HPLC) [12] and ion chromatography (IC) $[13,14]$. GC and HPLC methods might be able to achieve the necessary sensitivities but typically involve time consuming sample preparation steps such as extraction and/or derivatization. IC method which is commonly applied to organic acid analysis in various types of water is anion-excenge chromatography.[15, 16]

c. Hexavalent chromium

Hexavalent chromium, $\mathrm{Cr}(\mathrm{VI})$, is a highly toxic water pollutant with carcinogenic effects, mainly due to its strong oxidizing properties. Several methods have been described for the determination of hexavalent chromium. Non-chromatographic methods demand an extra step for the separation of trivalent and hexavalent forms of chromium. For this purpose many methods have been developed, based on, either the different ionic charge and using liquid-liquid extraction [17], cloud point extraction [18] and ionic solid phase extraction (SPE) [19] or the complex formation ability [20] of the two chemical states of chromium.

Chromatographic methods, also based on the aforementioned different properties of chromium species, have been developed, offering simplicity, speed, automation, and high sample throughput ability. HPLC methods are based on either the reversed phase separation of the $\mathrm{Cr}(\mathrm{VI})$ diphenylcarbazide complex [21] or the ion exchange separation of the $\mathrm{Cr}(\mathrm{VI})$ divalent chromate anion [22]. 
Ion chromatography can determine dissolved $\mathrm{Cr}(\mathrm{VI})$ as chromate in drinking water, groundwater, industrial wastewater, and solid waste extracts, conductivity beeing the most common detection mode in IC. Despite its lack of specificity, it is simple, fast, inexpensive, and results in enhanced sensitivity if a suppressor device is employed for the suppression of mobile phase conductivity.

In this research, a ion chromatography method for common inorganic anion was expanded to include measurement of three new components: acetate, formate and chromate.

\section{Experimental}

a. Materials

Chlorides Standard solution 1000 mg/l CertiPur Merck; Nitrites Standard solution 1000 mg/l CertiPur Merck; Bromides Standard solution 1000 mg/l CertiPur Merck; Nitrates Standard solution 1000 mg/l CertiPur Merck; Phosphates Standard solution 1000 mg/l CertiPur Merck; Sulphates Standard solution 1000 mg/l CertiPur Merck; Water. Monoelement Standard solution for IC: Acetate $\left(\mathrm{CH}_{3} \mathrm{COO}^{-}\right) 1000 \mathrm{mg} / \mathrm{L}$. Mono-element Standard solution for IC: Formiates (HCOO-) 1000 mg/L. Mono-element Standard solution for IC: Chromates $\left(\mathrm{CrO}_{4}^{2-}\right) 1000 \mathrm{mg} / \mathrm{L}$. All organic acids and chromate standards were purchased from CPAchem. Deionized water was produced in-house by first treating tap water by reverse osmosis and then passing the $\mathrm{RO}$ water through three ion-exchange sediment beds. DI water was used to make all solutions and canal water was used in the spike recovery analysis.

b. Instrumentation

A Thermo Scientific Dionex ICS-5000 Ion Chromatography System consisting of a Dionex ICS-5000-Dual Pump, an Dionex ICS-5000-Eluent Generator module, an Dionex ICS-5000-Detector/Chromatography Module, and an Dionex ICS-5000Conductivity Detector was used in the experiments. The Dionex ICS-5000 system is controlled by a PC configured with Thermo Scientific Dionex Chromeleon $^{\text {TM }} 7$ Chromatography Data System which provide complete instrument control, data acquisition, and data management. A Dionex lonPac AG22 guard column (4 X50 mm) and a Dionex IonPac AS22 analytical column (4X250 mm) were used in series for the separations of target analyte anions. The Dionex lonPac AS22 column provides excellent separation of the interest analytes using an isocratic $4,8 \mathrm{mM}$ carbonate/1,0 $\mathrm{mM}$ bicarbonate eluent and suppressed conductivity detection. Details of the IC system operating conditions are presented in Table 1.

Table 1. IC system operating conditions

\begin{tabular}{|l|l|}
\hline Column & Dionex lonPac AG22, AS22 \\
Eluent & $4,8 \mathrm{mM}$ sodium carbonate/1,0 mM sodium bicarbonate \\
Flow Rate & $1.0 \mathrm{~mL} /$ min \\
Temperature & $30^{\circ} \mathrm{C}$ \\
Inj. Volume & $10 \mu \mathrm{L}$ \\
Detection & Suppressed conductivity \\
\hline
\end{tabular}

c. Standard solution and sample preparation

Using the autosampler, water samples or standards were injected through a sample loop into the chromatographic system. The organic anions under investigation were separated from the inorganic anions using an isocratic $4.8 \mathrm{mM}$ carbonate $/ 1.0 \mathrm{mM}$ bicarbonate eluent. The mobile phase was prepared by diluting 1:100 an eluent concentrate solution from Dionex, containing $4.8 \mathrm{mM} \mathrm{Na}_{2} \mathrm{CO}_{3}$ and $1.0 \mathrm{mM} \mathrm{NaHCO}_{3}$ with deionised water. 
Two intermediate stock standard solution (at concentrations of $10 \mathrm{mg} / \mathrm{l}$ acetate, formiate, nitrite, bromide, phosphate and chormate and $100 \mathrm{mg} / \mathrm{l}$ chloride, nitrate and sulphate ) were obtained from the individual standard solutions. Working calibration standards were prepared daily at concentration levels of $0,1-1 \mathrm{mg} / \mathrm{I}$ from the $10 \mathrm{mg} / \mathrm{l}$ and $1-10 \mathrm{mg} / \mathrm{I}$ from the $100 \mathrm{mg} / \mathrm{l}$ intermediate stock solution. Figure 1. shows a typical chromatogram of a $1 \mathrm{mg} / \mathrm{l}$ nitrite, phosphate, bromide, acetate, formiate and chormate standard and $10 \mathrm{mg} / \mathrm{l}$ chloride, nitrate and sulphate standard . All calibration solutions were prepared by appropriate dilution and 0,45 $\mu \mathrm{m}$ pore diameter membrane syringe filters were used for sample particulate removal.

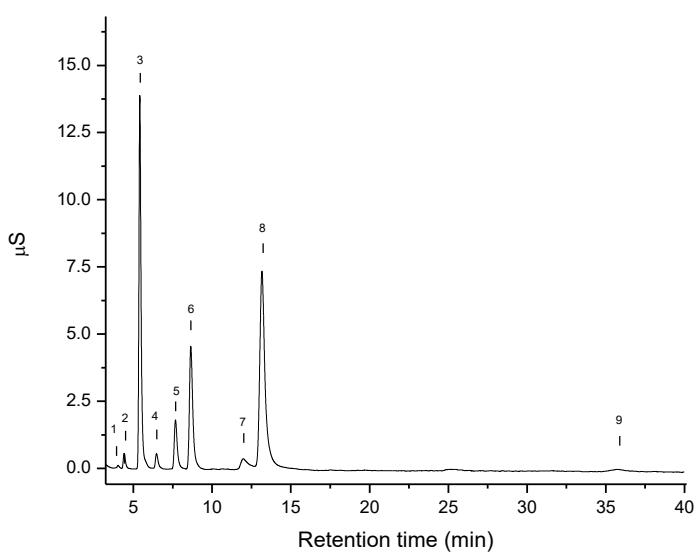

Fig. 1. Separation of high $\mathrm{mg} / \mathrm{l}$ level anions. Conditions: column Dionex lonPac AG 22 AS22; eluent $4.8 \mathrm{mM}$ sodium carbonate/1.0 mM sodium bicarbonate; fow rate 1.0 $\mathrm{ml} / \mathrm{min}$; detection suppressed conductivity with an ASRS operated at $27 \mathrm{~mA}$ in recycle mode; injection volum $100 \mu \mathrm{l}$; solutes 1 - acetate $(1 \mathrm{mg} / \mathrm{l}), 2$ - formiate (1 $\mathrm{mg} / \mathrm{l}), 3$ - chloride (10 mg/l), 4 - nitrite (1 mg/l), 5- bromide (1 mg/l ), 6 - nitrate (10 $\mathrm{mg} / \mathrm{l}), 7$ - phosphate $(1 \mathrm{mg} / \mathrm{I}), 8$ - sulphate $(10 \mathrm{mg} / \mathrm{l}), 10$ - chromate $(1 \mathrm{mg} / \mathrm{l})$.

\section{Results and Discussion}

The nine anions were separated by a $\mathrm{CO}_{3}{ }^{2-} / \mathrm{HCO}_{3}$ eluent according to the sequence presented in the chromatogram (Fig. 1) and the approximated retention times for the peaks of interest are indicated in Table 2.

Table 2. Retention times for target analyte anions

\begin{tabular}{|l|c|l|c|l|c|}
\hline \multicolumn{1}{|c|}{ Analyte } & Ret. time $(\mathrm{min})$ & \multicolumn{1}{|c|}{ Analyte } & Ret. time $(\mathrm{min})$ & Analyte & Ret. time (min) \\
\hline Acetate & 4,04 & Nitrite & 6,46 & Phosphate & 12,20 \\
Formate & 4,41 & Bromide & 7,69 & Sulphate & 13,16 \\
Chloride & 5,41 & Nitrate & 8,67 & Chromate & 35,37 \\
\hline
\end{tabular}

The method was validated in the laboratory by checking performance parameters such as linearity, detection and the quantification limit, repeatability, reproductibility and intermediate precision.

a. Linearity

Linearity test solutions were prepared by diluting the stock solutions to the required concentrations. The calibration curves were obtained for each analytes of interest at the same time. Experiments run at six concentration levels gave linear fit for all ions in terms of peak area as shown in figures 2 and 3 . 

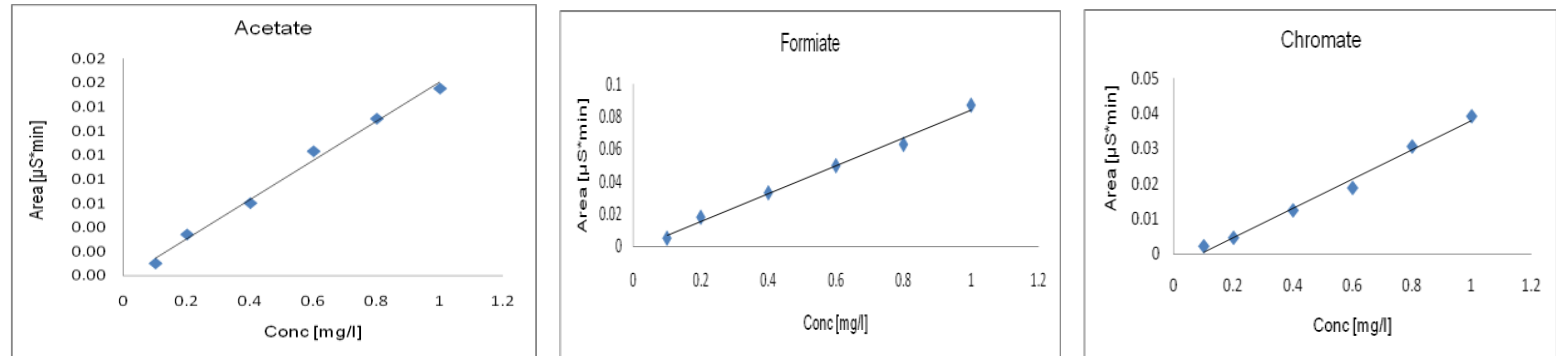

Fig. 2. Calibration curves for acetate, formiate and chromate

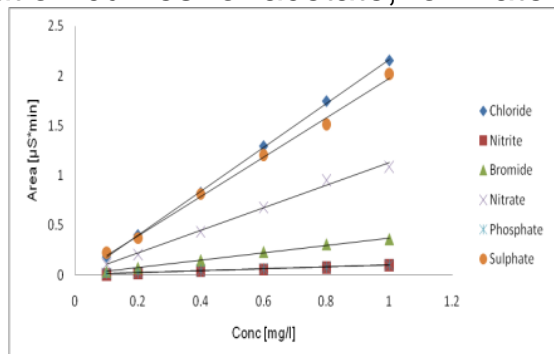

Fig 3: Adjusted calibration curves generated from linear range data for the common anions

As shown, the tendency lines were fit to a curve in order to get satisfactory accuracy and precision at high concentration levels, obtaining correlation coefficients higher than 0,99 in all cases with exception of chromate anion for which was determined a correlation coefficients across 0,98 . The equations for the calibration curves and their correlation coefficients can be found in Table 3 .

Table 3. Linear regressions and $\mathrm{R}^{2}$ values from Figure 2 and Figure 3

\begin{tabular}{|l|c|c|c|c|}
\hline \multicolumn{1}{|c|}{ Analyte } & $\begin{array}{c}\text { Range } \\
(\mathrm{mg} / \mathrm{l})\end{array}$ & $\begin{array}{c}\text { Calibration Curve } \\
\text { Equation }\end{array}$ & $\begin{array}{c}\text { Correlation } \\
\text { Coefficient }\left(\mathrm{R}^{2}\right)\end{array}$ & $\mathrm{RSD}(\%)$ \\
\hline Acetate & $0.1-1.0$ & $\mathrm{y}=0.016 \mathrm{x}$ & 0.991 & 6,2105 \\
\hline Formate & $0.1-1.0$ & $\mathrm{y}=0.086 \mathrm{x}-0.002$ & 0.992 & 6,8895 \\
\hline Chloride & $1.0-10$ & $\mathrm{y}=2.200 \mathrm{x}-0.034$ & 0.999 & 2,1869 \\
\hline Nitrite & $0.1-1.0$ & $\mathrm{y}=0.103 \mathrm{x}-0.001$ & 0.991 & 6,8523 \\
\hline Bromide & $0.1-1.0$ & $\mathrm{y}=0.373 \mathrm{x}-0.000$ & 0.995 & 4,4067 \\
\hline Nitrate & $1.0-10$ & $\mathrm{y}=1.134 \mathrm{x}-0.005$ & 0.994 & 5,0922 \\
\hline Phosphate & $0.1-1.0$ & $\mathrm{y}=0.097 \mathrm{x}+0.007$ & 0.998 & 9,7415 \\
\hline Sulphate & $1.0-10$ & $\mathrm{y}=1.974 \mathrm{x}-0.038$ & 0.996 & 9,2718 \\
\hline Chromate & $0.1-1.0$ & $\mathrm{y}=0.041 \mathrm{x}-0.003$ & 0.988 & 4,5267 \\
\hline
\end{tabular}

All of the \% RSD's were well below $10 \%$, showing that this method is very precise. There is also a wide range of sensitivities in the nine anions analyzed.

b. Detection and the quantification limit

The detection limit $(D L)$ and the quantification limit $(Q L)$ for common anions, organic acids and chromate were determined by measuring the smallest standar solution 0,1 $\mathrm{mg} / \mathrm{l}$ for nitrite, phosphate, bromide, acetate, formiate and chromate respectively $1 \mathrm{mg} / \mathrm{l}$ for chloride, nitrate and sulphate, five times under the same analytical conditions and were calculated at a 95\% confidence level. The analytical results are presented in Table 4.

Table 4. Limits of detection and quantitation

\begin{tabular}{|l|c|c|c|c|c|c|c|c|}
\hline Analyte & $\begin{array}{c}\mathrm{DL} \\
(\mathrm{mg} / \mathrm{l})\end{array}$ & $\mathrm{QL}(\mathrm{mg} / \mathrm{l})$ & Analyte & $\begin{array}{c}\mathrm{DL} \\
(\mathrm{mg} / \mathrm{l})\end{array}$ & $\mathrm{QL}(\mathrm{mg} / \mathrm{l})$ & Analyte & $\begin{array}{c}\mathrm{DL} \\
(\mathrm{mg} / \mathrm{l})\end{array}$ & $\mathrm{QL}(\mathrm{mg} / \mathrm{l})$ \\
\hline Acetate & 0,033 & 0,113 & Nitrite & 0,036 & 0,122 & Phosphate & 0,036 & 0,122 \\
\hline Formate & 0,030 & 0,100 & Bromide & 0,039 & 0,137 & Sulphate & 0,169 & 0,563 \\
\hline Chloride & 0,224 & 0,748 & Nitrate & 0,218 & 0,728 & Chromate & 0,051 & 0,167 \\
\hline
\end{tabular}


c. Repeatability

The repeatability test, checking the consistency of calculated results for the analyte peak over a short time period, by the same user, on the same instrument are collected in Table 5. The relative standard deviations of the peak areas vary between 2.43 and $4.10 \%$

Table 5. Repeatability

\begin{tabular}{|l|c|c|c|c|c|}
\hline \multicolumn{1}{|c|}{ Analyte } & $\begin{array}{c}\text { Real } \\
\text { concentration } \\
(\mathrm{mg} / \mathrm{l})\end{array}$ & $\begin{array}{c}\text { Mean } \\
\text { concentration } \\
(\mathrm{mg} / \mathrm{l})\end{array}$ & $\mathrm{sr}(\mathrm{mg} / \mathrm{l})$ & $\mathrm{RSD}$ \% & $\begin{array}{c}\text { Repetability } \\
(\mathrm{r})\end{array}$ \\
\hline Acetate & 0,4 & 0,403 & 0,011 & 2,80 & 0,032 \\
\hline Formate & 0,4 & 0,407 & 0,010 & 2,43 & 0,028 \\
\hline Chloride & 2,0 & 2,056 & 0,075 & 3,64 & 0,209 \\
\hline Nitrite & 0,4 & 0,412 & 0,012 & 2,95 & 0,034 \\
\hline Bromide & 0,4 & 0,413 & 0,013 & 3,32 & 0,038 \\
\hline Nitrate & 2,0 & 2,066 & 0,073 & 3,53 & 0,204 \\
\hline Phosphate & 0,4 & 0,407 & 0,012 & 3,00 & 0,034 \\
\hline Sulphate & 2,0 & 2,055 & 0,056 & 2,74 & 0,157 \\
\hline Chromate & 0,4 & 0,407 & 0,017 & 4,10 & 0,047 \\
\hline
\end{tabular}

\section{d. Intermediate precision}

The intra-laboratory consistency of measurements was checked using standard solutions at two concentration levels, prepared daily, for three consecutive days. Analyses were performed by two different operators on the same instrument, yielding values of relative standard deviations varying between 3,47 and $8,28 \%$ (Tables 6 ), higher than those obtained under repeatability conditions (table 5). In conclusion, the method presents intermediate precision at all levels of concentration studied.

Table 6. Intermediate precision

\begin{tabular}{|l|c|c|c|c|c|c|}
\hline \multirow{2}{*}{ Analyte } & \multirow{2}{*}{$\begin{array}{c}\text { Real } \\
\text { concentration } \\
\end{array}$} & \multicolumn{2}{|c|}{$\begin{array}{c}\text { Mean concentration } \\
(\mathrm{mg} / \mathrm{l})\end{array}$} & $\begin{array}{c}\mathrm{S}_{\mathrm{R}} \\
(\mathrm{mg} / \mathrm{l})\end{array}$ & RSDr \% & \multirow{2}{*}{$\begin{array}{c}\text { Reproductibility } \\
(\mathrm{R})\end{array}$} \\
\cline { 3 - 4 } & Analyst 1 & Analyst 2 & & & \\
\hline Acetate & 0,4 & 0,419 & 0,417 & 0,029 & 7,01 & 0,082 \\
\hline Formate & 0,4 & 0,411 & 0,415 & 0,024 & 5,92 & 0,068 \\
\hline Chloride & 2,0 & 2,093 & 2,104 & 0,288 & 13,7 & 0,805 \\
\hline Nitrite & 0,4 & 0,417 & 0,402 & 0,025 & 6,03 & 0,071 \\
\hline Bromide & 0,4 & 0,415 & 0,412 & 0,019 & 4,53 & 0,053 \\
\hline Nitrate & 2,0 & 2,110 & 2,137 & 0,176 & 8,28 & 0,492 \\
\hline Phosphate & 0,4 & 0,410 & 0,415 & 0,014 & 3,47 & 0,040 \\
\hline Sulphate & 2,0 & 2,077 & 2,087 & 0,155 & 7,43 & 0,433 \\
\hline Chromate & 0,4 & 0,410 & 0,421 & 0,021 & 5,14 & 0,060 \\
\hline
\end{tabular}

\section{e. $\quad$ Measurement uncertainty}

The measurement uncertainty was estimated according to "Guide to the Expression of Uncertainty in Measurement (GUM).[23] Precision data for the calculation of random uncertainty components were taken from control charts, from replicate analyses and calibration experiments. Systematic uncertainty components were calculated for a concentrantion level of the $0,6 \mathrm{mg} / \mathrm{L}$ nitrite, phosphate, bromide, acetate, formiate and chromate and $6 \mathrm{mg} / \mathrm{l}$ chloride, nitrate and sulphate standard reference solutions. Random and systematic uncertainty contributions were merged for the calculation of the combined measurement uncertainty $u_{c}$. Multiplication of $u_{\mathrm{c}}$ by 2 gave a resulting expanded measurement uncertainty $(\mathrm{U} \%)$ as presented in Tabel 7. 
Table 7. Measurement uncertainty

\begin{tabular}{|l|c|c|l|c|c|c|c|c|}
\hline Analyte & Conc. $(\mathrm{mg} / \mathrm{l})$ & $\mathrm{U}(\%)$ & Analyte & Conc. $(\mathrm{mg} / \mathrm{l})$ & $\mathrm{U}(\%)$ & Analyte & Conc. $(\mathrm{mg} / \mathrm{l})$ & $\mathrm{U}(\%)$ \\
\hline Acetate & 0,6 & 17,4 & Nitrite & 0,6 & 14,6 & Phosphate & 0,6 & 14,8 \\
\hline Formate & 0,6 & 11,2 & Bromide & 0,6 & 16,1 & Sulphate & 6,0 & 12,7 \\
\hline Chloride & 6,0 & 12,3 & Nitrate & 6,0 & 17,3 & Chromate & 0,6 & 21,4 \\
\hline
\end{tabular}

f. Analytical results

The method was applied to the determination of commun anions, organic acids and chromate in laboratory synthetic sample containing three different concentrations 0,2 , 0,5 respectively $0,9 \mathrm{mg} / \mathrm{l}$ of acetate, formiate and chromate in drinking water matrices. Cromatograms for these samples are represented in figure 4, and the determined concentrations are collected in Table 8.
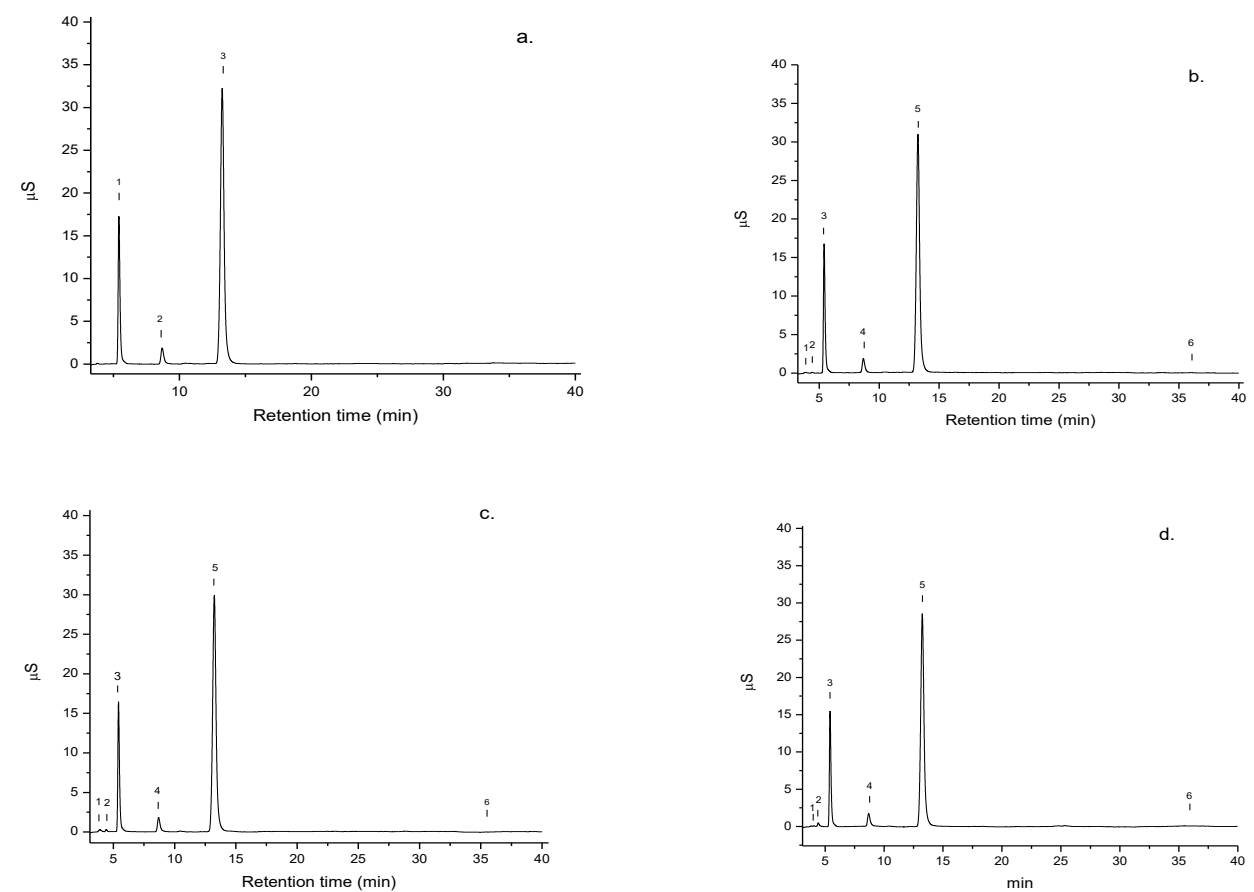

Fig 4. The chromatogram obtained for the a.drinking water sample (with 1- chloride, 2 - nitrate, 3 - sulphate) and the synthetic samples containing added standard solutions concentration b. $0,2 \mathrm{mg} / \mathrm{L}$, c. $0,5 \mathrm{mg} / \mathrm{l}$ and d. 0,9mg/l acetate, formate and chromate. (solutes 1 - acetate , 2 formate, 3 - chloride, 4 - nitrate, 5 - sulphate , 6 -chromate)in drinking water matrices.

Table 8. Drinking water and synthetic sample results

\begin{tabular}{|l|c|c|c|c|c|c|c|}
\hline \multirow{2}{*}{ Analyte } & $\begin{array}{c}\text { Drinking water } \\
\text { sample a }\end{array}$ & \multicolumn{2}{|c|}{$\begin{array}{c}\text { Synthetic } \\
\text { sample b }\end{array}$} & \multicolumn{2}{c|}{$\begin{array}{c}\text { Synthetic } \\
\text { sample c }\end{array}$} & \multicolumn{2}{c|}{$\begin{array}{c}\text { Synthetic } \\
\text { sample d }\end{array}$} \\
\cline { 2 - 8 } & Conc. (mg/l) & $\begin{array}{c}\text { Conc. } \\
(\mathrm{mg} / \mathrm{l})\end{array}$ & $\mathrm{RSD} \%$ & $\begin{array}{c}\text { Conc. } \\
(\mathrm{mg} / \mathrm{l})\end{array}$ & $\mathrm{RSD} \%$ & $\begin{array}{c}\text { Conc. } \\
(\mathrm{mg} / \mathrm{l})\end{array}$ & RSD\% \\
\hline Acetate & - & 0,20 & 3,63 & 0,51 & 3,18 & 0,76 & 2,92 \\
\hline Formate & - & 0.19 & 3,82 & 0,46 & 3,40 & 0,91 & 3,26 \\
\hline Chloride & 12,82 & 12,68 & 1,08 & 12,32 & 0,40 & 11,72 & 1,24 \\
\hline Nitrite & - & - & - & - & - & - & - \\
\hline Bromide & - & - & - & - & - & - & - \\
\hline Nitrate & 4,11 & 4,24 & 1,33 & 4,08 & 1,04 & 3,99 & 2,09 \\
\hline Phosphate & - & - & - & - & - & - & - \\
\hline Sulphate & 55,70 & 53,52 & 1,66 & 51,80 & 1,28 & 49,74 & 1,06 \\
\hline Chromate & - & 0,19 & 3,42 & 0,47 & 3,17 & 0,91 & 3,08 \\
\hline
\end{tabular}




\section{Conclusions}

It was developed a new method for simultaneous determination of two organic acids, acetate and formate and chromium VI in form of chromate anion by improving the method for determining common anions such as chloride, nitrite, bromide, nitrate, phosphate and sulphate. The results obtained from analyzing synthetic drinking water samples suggest that the new IC method developed in this study can be applied to determine target anions in a wide range of drinking water sample matrices.

\section{References}

[1] P.R. Haddad, P.E. Jackson, (1990), 'Ion Chromatography: Principles and Applications', Journal of Chromatography A, Library, Elsevier, Amsterdam, 46.

[2] C.A. Pohl, J.R. Stillian, P.E. Jackson, (1997), 'Factors Controlling lon-exchange Selectivity in Suppressed lon Chromatography', Journal of Chromatography A, 789, 29-41.

[3] J. Weiss, (1995), Ion Chromatography, 2nd edition, VCH, Weinheim.

[4] R. Michalski, (2006), 'Ion Chromatography as a Reference Method for Determination of Inorganic lons in Water and Wastewater', Critical Reviews in Analytical Chemistry, 36, 107127

[5] Europian Standard SR EN ISO 10304-1:2003: Water quality: Determination of dissolved fluoride, chloride, nitrite, orthophosphate, bromide, nitrate and sulphate ions, using liquid chromatography of ions. Part 1: Method for water with low contamination

[6] Method 300.1: Determination of Inorganic Anions in Drinking Water by lon Chromatography; U.S. Environmental Protection Agency, National Exposure Research Laboratory, Office of Research and Development: Cincinnati, Ohio, (1997).

[7] A. E. Greenberg, L. S. Clesceri, A. D. Eaton, (1992) Eds.; Standard Methods for the Examination of Water And Wastewater, $18^{\text {th }}$ ed.; American Public Health Association: Washington, DC

[8] Standard Test Methods for Anions in Water by Chemically Suppressed Ion Chromatography; American Society for Testing and Materials; West Conshohocken, PA; (1999), D4327-97, 11, 420-427.

[9] P.R. Haddad, P.E. Jackson, (1990), Ion Chromatography: Principles and Applications, Journal of Chromatography, Library, 46, Elsevier, Amsterdam.

[10] W.E. Coleman, J.W. Munch, H.P. Ringhand, W.H. Kaylor, D.E. Mitchell, (1992), 'Ozonation/Post-Chlorination of Humic Acid: A Model for Predicting Drinking Water Disinfection By-Products', Ozone Science \& Engineering Journal, 14, 51-69.

[11] Y. Xie and D.A. Reckhow, (1992) 'Formation of Ketoacids in Ozonated Drinking Water', Ozone Science \& Engineering Journal, 14, 269.

[12] S. Allenmark, M. Chelminska-Bertilsson, R.A. Thompson, (1990), 'N-(9-Acridinyl) bromoacetamide-A Powerful Reagent for Phase-Transfer-Catalyzed Fluorescence Labeling of Carboxylic Acids for Liquid Chromatography', Analytical Biochemistry. 185, 279-285.

[13] Sigrid Peldszus*, Peter M. Huck, Susan A. Andrews, (1998), 'Quantitative determination of oxalate and other organic acids in drinking water at low $\mathrm{mg} /$ I concentrations', Journal of Chromatography A, 793, 198-203

[14] Xiumei Geng, Sufang Zhang, QianWang, Zongbao (Kent) Zhao, (2008), 'Determination of organic acids in the presence of inorganic anions by ion chromatography with suppressed conductivity detection', Journal of Chromatography A, 1192, $187-190$

[15] J. Chen, (1996), 'Determination of organic acids in industrial streams by ion chromatography after solid-phase extraction', Journal of Chromatography A, 739, 273-280.

[16] C.Y. Kuo, (1998) 'Improved application of ion chromatographic determination of carboxylic acids in ozonated drinking water', Journal of Chromatography A, 804, 265-272

[17] A. S. Stasinakis, N. S. Thomaidis and T. D. Lekkas. (2003). 'Speciation of chromium in wastewater and sludge by extraction with liquid anion exchanger Amberlite LA-2 and electrothermal atomic absorption spectrometry.' Analytica Chimica Acta, 478, 119-127. 
[18] E. K. Paleologos, C. D. Stalikas, and M. I. Karayannis, (2001), 'An optimized singlereagent method for the speciation of chromium by flame atomic absorption spectrometry based on surfactant micelle-mediated methodology'. Analyst, 126, 389-393.

[19] D. H. Chen, M. He, C. Z. Huang, and B. Hu. (2008). 'Speciation of chromium in environmental water samples using chitosan-modified ordered mesoporous silica as solid phase extraction material and determination by inductively coupled plasma optical emission spectrometry', Atomic spectroscopy , 29: 165-171.

[20] A. Tunceli, and A. R. Turker, (2002), 'Speciation of $\mathrm{Cr}(\mathrm{III})$ and $\mathrm{Cr}(\mathrm{VI})$ in water after preconcentration of its 1,5-diphenylcarbazone complex on amberlite XAD-16 resin and determination by FAAS'. Talanta, 57, 1199-1204.

[21] A. Padarauskas, A. Judzentiene, E. Naujalis, and V. Paliulionyte. (1998). 'On-line preconcentration and determination of chromium $(\mathrm{VI})$ in waters by high-performance liquid chromatography using precolumn complexation with 1,5-diphenylcarbazide'. Journal of Chromatography A, 808, 193-199.

[22] R. E. Wolf, J. M. Morrison, and M. B. Goldhaber. (2007). 'Simultaneous determination of $\mathrm{Cr}(\mathrm{III})$ and $\mathrm{Cr}(\mathrm{VI})$ using reversed-phased ion-pairing liquid chromatography with dynamic reaction cell inductively coupled plasma mass spectrometry'. Journal of Analytical Atomic Spectrometry, 22, 1051-1060.

[23] Evaluation of measurement data - Guide to the expression of uncertainty in measurement, JCGM 100:2008 